\title{
KIERKEGAARD E PLANTINGA: A SUBJETIVIDADE E A CRENÇA EM DEUS
}

\section{KiERKEgAaRd AND Plantinga: SUBJECTIVITY AND BELIEF IN GOD}

Marcio de Paula Gimenes*

RESUMO - O objetivo do presente trabalho é apresentar a discussão da temática da subjetividade como um importante fator para a afirmação da crença religiosa, tanto na obra de Kierkegaard como na obra de Plantinga. A despeito de algumas diferenças conceituais, avaliamos que ambos os autores não se interessam por provar a existência de Deus, mas antes se concentram na experiência como um fator central. Além disso, em ambos os autores, e na tradição cristã em geral, a subjetividade é fundamental para a afirmação da crença. Em Kierkegaard, tal conceito se encontra com a afirmação da fé enquanto absurdo. Em Plantinga, a afirmação da "basicalidade da crença" abre espaço para a relação de experiência e amplia o debate sobre a crença, reafirmando a sua posição crítica aos fundamentos da modernidade. Desse modo, a partir de alguns recortes específicos, busca-se o estabelecimento de um diálogo que consegue apontar, mesmo com diferenças essenciais entre os dois autores, notadamente na questão do absurdo e na ênfase maior de Kierkegaard sobre a fé como algo apaixonado, um fecundo debate.

PALAVRAS-CHAVE - Kierkegaard. Plantinga. Subjetividade. Crença. Filosofia da religião.

ABSTRACT - The aim of this paper is to present a discussion of the issue of subjectivity as an important factor for the affirmation of religious belief in both the work of Kierkegaard and Plantinga. Despite some conceptual differences, we conclude that both authors are not interested in proving God's existence, but rather focus on experience as a central factor. In addition, for both authors, and the

* Doutor em Filosofia pela UNICAMP (2005). Professor do Departamento de Filosofia da Universidade de Brasília. Endereço: Universidade de Brasília, Departamento de Filosofia - ICC Norte, Campus Universitário Darcy Ribeiro, Asa Norte, CEP 70910-900, Brasília-DF. <marciogimenes@unb.br>.

\begin{tabular}{|l|l|l|l|l|l|}
\hline Veritas & Porto Alegre & v. 56 & n. 2 & maio/ago. 2011 & p. 32-46 \\
\hline
\end{tabular}


Christian tradition in general, the subjectivity is fundamental to the affirmation of belief. In Kierkegaard the concept is the affirmation of faith as absurd. In Plantinga's assertion "basical belief" makes room for the relationship of experience and expands the debate about belief, reaffirming its critical position to the foundations of modernity. Thus, from some specific approaches, we seek to establish a dialogue that, despite essential differences between the two authors, above all the theme of the absurdity of faith and Kierkegaard's emphasis on faith as something passionate, can point out to a fruitful debate.

KEYWORDS - Kierkegaard. Plantinga. Subjectivity. Belief. Philosophy of religion.

\section{A subjetividade em Kierkegaard}

Tentar apontar uma possível relação entre Kierkegaard e Plantinga é algo que carece de uma explicação preliminar. Afinal, Kierkegaard parece ter se afirmado como um dos pensadores que tem uma grande dificuldade para conciliar fé e conhecimento. A fé expressaria, para ele, um tipo tal de confiança que dispensaria qualquer prova da existência divina, o que parece até mesmo coerente para um pensador que vem depois de Kant, onde as provas e os argumentos para a fé ou a crença em Deus parecem ter perdido o seu sentido. Tal confiança também dispensaria qualquer tipo de certeza ou justificação da fé. Tal como se pode perceber por este trecho da sua obra Post-Scriptum às Migalhas Filosóficas:

Mas, a definição dada de verdade é uma transcrição da fé. Sem risco não há fé. A fé é justamente a contradição entre a paixão infinita da interioridade e a incerteza objetiva. Se posso conceber a Deus objetivamente, então eu não creio; se quero conservar a fé, devo ter sempre presente no espírito que mantenho a incerteza objetiva, que me encontro na incerteza objetiva 'sobre uma profundidade de setenta mil pés de água' e que, não obstante, eu creio ${ }^{1}$.

Nesse sentido, Desidério Murcho parece ter razão quando afirma que "Kierkegaard considera a fé incompatível com o conhecimento, por este último implicar a justificação, ao passo que a fé implica o risco epistêmico"2. Para Kierkegaard, a fé implica em risco e não em qualquer tipo de segurança ou justificação. Desejar tal coisa é estar fora do aspecto apaixonado que é intrínseco ao próprio ato de crer.

1 Cf. S. A. Kierkegaard, Post-Scriptum Définitif et non scientifique aux miettes philosophiques, vol. I/II - Oeuvres Complètes, vols. 10/11, Paris: Éditions L'Orante, 1977, p. 190.

2 Cf. D. Murcho, fé, epistemologia e virtude, in: Critica na Rede, <www.criticanarede. com >. Acessado em 22.08.2011. 
Desse modo, avaliamos que um ponto importante a se destacar no diálogo entre Kierkegaard e Plantinga talvez seja exatamente o aspecto subjetivo da fé cristã, pois a mesma parece ser comum a ambos os autores. O cristianismo exige a subjetividade de todos os homens, ele se destina a todos e, diferentemente da especulação, não se dirige apenas aos mais preparados intelectualmente. No entender de Clímacus, pseudônimo autor das obras Migalhas Filosóficas e Post-Scriptum às Migalhas Filosóficas, transformar a fé cristã em algo objetivo é torná-la restrita a um seleto grupo, é torná-la um gênero de mistificação e de esoterismo. Por isso, ele segue a trilha de Tertuliano, e acredita que a fé cristã se afirma na força do absurdo.

Assim como no paganismo Sócrates se declara ignorante, a proposta kierkegaardiana declara e defende que a fé cristã deve basear-se no absurdo. Cabe ressaltar, contudo, que Kierkegaard não defende nenhuma espécie de concepção irracionalista. O seu intuito é enfatizar que a razão, tal como a concebem os pensadores especulativos, não é capaz de dar conta da totalidade. Ele usa a expressão absurdo no seu sentido pleno, ou seja, algo que não pode ser explicado logicamente. A sua frase pode ser entendida, com os devidos cuidados, na esteira da interpretação do célebre pai da Igreja: "creio visto que é absurdo" (credo quia absurdum est). Tal frase, se é que ela foi mesma proferida, sinaliza algo que não pode ser explicado. Aquilo que pode ser explicado não precisa de nenhuma crença, como observa Paul Tillich:

Na verdade [Tertuliano] disse o seguinte: 'O Filho de Deus morreu: devemos crê-lo porque é absurdo. Foi sepultado e ressuscitou; o fato é incontestável porque é impossível'. Esse paradoxo resultava de dois fatores: em primeiro lugar, expressava a realidade surpreendente e inesperada do aparecimento de Deus nas condições da existência; em segundo lugar, era a expressão retórica dessa ideia do modo como os oradores romanos utilizavam a língua latina. Não era para ser concebido literalmente. O paradoxo, porém, servia para indicar a realidade incrível do aparecimento de Cristo. Era natural que se acrescentasse a essa fórmula a expressão, credo quia absurdum est, muito embora Tertuliano nunca a tivesse escrito. Não se pode esperar que escrevesse com tamanha clareza, dada a sua maneira de fazer teologia, uma vez que, como estóico, acreditava no poder determinante do Logos ${ }^{3}$.

Segundo o pensador dinamarquês, o absurdo é o ponto mais profundo da fé. Para Sócrates, a verdade eterna é reminiscência e, por isso, não pode ser paradoxal. A verdade eterna vista socraticamente é sempre algo interno. A proposta kierkegaardiana se configura, notadamente

3 Cf. Paul Tillich, História do pensamento cristão, São Paulo: Aste, 1988, p. 100. 
nesse ponto, como uma tentativa de operar uma espécie de reforma da filosofia socrática, adaptando-a aos seus objetivos. Para a perspectiva socrática, a verdade eterna pode ser encontrada pela reminiscência. Já para Kierkegaard, a verdade eterna é o deus que surge no tempo, impulsionando o sujeito, por sua paixão, a existir e realizar a síntese entre finito e infinito.

O pensador de Copenhague chama de não-verdade o estado do sujeito que ainda não existe, o estado de pecado (vejamos aqui as Migalhas Filosóficas, onde a pista é claramente agostiniana). Para ele, o homem não nasce pecador, mas no pecado. Tal coisa seria, no seu entender, o pecado original, melhor explicitado pelo pseudonímico Vigilius Haufniensis, em Conceito de Angústia. O paradoxo seria, portanto, a soma da verdade eterna essencial e da existência. Aqui há uma clara diferença entre a concepção kierkegaardiana e a visão hegeliana: para o filósofo alemão, a verdade está sempre no passado, por isso os seres humanos devem buscála através da história. Ela é um modelo teórico que começa na dialética de Platão e chega até os dias atuais. Já na filosofia de Kierkegaard, a busca da verdade é sempre feita com passos à frente, a verdade está à frente, sendo eterna, mas manifestando-se no tempo. Por isso, o indivíduo não pode nunca se apossar dela.

O paradoxo seria, portanto, um choque entre a interioridade do existente e a ignorância objetiva. Para Kierkegaard, embora a filosofia socrática (na sua vertente platônica) nos tenha levado ao pensamento objetivo, Sócrates, ele mesmo, privilegiava o interior. A diferença entre a resignação socrática e a fé é que a primeira baseia-se na ignorância e a segunda no absurdo. $\mathrm{O}$ absurdo seria uma manifestação da verdade no tempo, operando o contato do existente com o paradoxo. Nesse sentido, por exemplo, a figura de Abraão em Temor e Tremor configura-se como um ponto essencial da diferença entre o projeto socrático e o projeto cristão: o patriarca israelita crê no absurdo, Sócrates é ignorante e resignado ao seu destino.

A fé promove um escândalo em uma época de tantas certezas. O escândalo advém do absurdo da própria fé. A fé não é algo para a massa, mas para o indivíduo, como sugere Clair: "Na obra de Kierkegaard, o tema do Indivíduo não é somente um elemento acessório ou marginal ou ainda derivado. Ele é o elemento central a partir do qual todas as questões e todas as obras obtêm sua significação. O próprio Kierkegaard foi muito explícito sobre esse ponto"4.

4 Cf. A. Clair, Pseudonymie et Paradoxe - la pensée dialectique de Kierkegaard, Paris: J. Vrin, 1976, p. 320. 
A importância central da questão do indivíduo na obra kierkegaardiana também pode ser conferida nos seus Diários: "Para mim, não pessoalmente, mas como pensador, essa questão do singular é a mais decisiva" 5 .

Uma fé intelectual, no entender kierkegaardiano, seria uma comédia. Ainda pior: ela confundiria o pseudo-cristianismo com a verdade eterna. Tal coisa seria uma desfiguração; por isso, aos seus olhos, a especulação consiste em uma tentação. A experiência do ser divino deve ocorrer a partir da existência humana concreta e não da abstração. Por isso, o paradoxo é vital e não se pode suprimi-lo, como faz o sistema. O próprio cristianismo é um mistério, logo não há espaço para um academicismo cristão.

Se o deus se manifesta no tempo (paradoxo), o homem é impelido a tomar uma decisão. Exatamente aqui, reside o escândalo. É preciso que se tenha decisão na interioridade para se chegar à verdade. $O$ paradoxo explicado não é mais paradoxo. Nesse sentido, Kierkegaard prefere Feuerbach aos pastores da Dinamarca. Ele ao menos sabe o que recusa, diferentemente desses, que parecem não saber o que aceitam. O paradoxo se transforma em retórica para a especulação, que usa da arrogância socrática para combater os cristãos apaixonados, mas não usa da sua existência para fazer a sua própria crítica. Tal especulação retira o discípulo do caminho, lançando-o no erro.

$\mathrm{Na}$ visão kierkegaardiana, o pensador subjetivo, ao fazer a analogia da existência à verdade, traz mais coisas negativas do que positivas. Há nisso algo de cômico e passional. O pensador subjetivo está continuamente no devir, no esforço. O ser humano existente se afirma no devir, devendo a essência corresponder à forma da sua existência. É bem verdade, observa Kierkegaard, que Hegel tornou conhecida a dialética do devir. Para Hegel, o negativo é algo marginal e a sua função é, no devir, tornarse positivo. No positivo reside a certeza sensível, o saber histórico e o resultado especulativo. Para Kierkegaard, esse positivo é a não-verdade. Afinal, a certeza sensível é uma zombaria, o saber histórico é uma ilusão dos sentidos, e o resultado especulativo é uma fantasmagoria. O positivo hegeliano não é capaz de exprimir o estado do sujeito conhecedor da existência, antes conduz a um sujeito objetivo fictício e deixa-se enganar a si mesmo por tal sujeito, assim permanecendo.

Quando o sujeito é existente, a especulação se torna ilusória. Não adianta o saber histórico possuir informações sobre o mundo, mas nada saber sobre si próprio. Nada daquilo que é histórico pode vir a ser absolutamente certo, só o que existe possui tal condição. O resultado

5 Cf. A Clair, Kierkegaard, penser le singulier, Paris: Cerf, 1993, p. 07 (extraída dos Diários de Kierkegaard: pap. XIII 643, apud). 
especulativo é uma ilusão, uma vez que o sujeito abstrai a sua própria existência. O negativo é mais presente ao existente, o positivo sofre um engano. O negativo se afirma na existência, ele é a negatividade do sujeito que existe. Além disso, ele é fundado sobre a síntese do sujeito, que é um espírito infinito existente. Já o que é eterno não vem a ser e nem pode tomar nenhuma forma. A posição objetiva, através dos seus muitos enunciados, oculta o sujeito e lhe retira a existência. O sujeito existente é eterno, mas enquanto existe é temporal. Kierkegaard julga as certezas positivas como suspeitas. Por isso, na sua visão, a ideia de história mundial é um projeto impossível.

Para a posição objetiva, por exemplo, Sócrates não passa de um preguiçoso que só olha para si mesmo. Tal objetividade jamais entenderia e nem resistiria à sua ironia. A abordagem socrática do infinito é sempre feita em tom jocoso, fazendo uso do mal-entendido. Sócrates encontra a ideia do incerto (o não sei). Em outras palavras, ele não desenvolve a dialética da ideia, mas a ideia da dialética ${ }^{6}$. O pensador subjetivo, tal como Sócrates, possui o infinito em sua alma. Ele o possui sempre, visto que a sua forma não cessa de ser negativa. O negativo é o ser humano que sempre aprende mais do que ensina, isto é, o que se esforça. Aos que se esforçam não há estabilidade possível e nem interesses de acordo com os ditames do sistema. Assim ocorreu com Sócrates, que não foi professor, sendo mais negativo do que positivo.

Do ponto de vista objetivo se fala da coisa em si, subjetivamente se fala do sujeito e da subjetividade. O problema é que a decisão equivale à subjetividade. A aceitação de algo pela objetividade equivale, para Kierkegaard, a paganismo, isto é, falta de reflexão. A verdade em um e para um indivíduo, isto é, a apropriação da verdade na interioridade (no cristianismo), vale mais do que a história mundial. Ser subjetivo é um esforço e não uma banalidade. Enquanto a ciência leva à objetividade, o cristianismo conduz à subjetividade, sendo a vida humana a potencialização de uma paixão. A piedade reside na subjetividade e não na objetividade e em instituições.

A tendência objetiva faz das pessoas espectadoras da situação e pretensamente éticas. Contudo, só pode fazer discípulos quem é, de fato, discípulo. Essa é a diferença entre os servidores de um rei terreno e um cristão: o último precisa ser sincero. A ética é vista como um tribunal quando, de fato, o juízo deve caber a Deus. A ética é o ponto mais alto na relação entre os homens, mas não é capaz de abranger todas as coisas. No processo da dialética da história mundial, a ética passa a residir nessa,

Tal tese, de Sócrates como pensador negativo, já apareceu no Conceito de ironia, de Kierkegaard. 
deslocando-se do âmbito do indivíduo. Ela é a reafirmação do indivíduo que, segundo a história mundial, não é nada. Por isso, a história mundial é, para Kierkegaard, um conceito arbitrário hegeliano e menor do que a ideia de salto (subjetividade/interioridade). A história mundial se constitui em um engano para a própria ciência e torna-se uma espécie de passatempo diante da ética. A crítica kierkegaardiana ao sistema, afirmará que esse não enxerga a história mundial em concreto, mas abstratamente, acaba por ocorrer um confronto entre história mundial especulativa e a história dos indivíduos. Se a história mundial é, de fato, a história do gênero humano, ela deve envolver a ética. Aquele que contempla a história, apenas a vê por uma perspectiva metafísica, percebendo especulativamente a imanência de causa e efeito e as suas conseqüências posteriores. Contudo, o seu télos não é ético, mas metafísico.

A diferença entre a história mundial e a ética é que a ética possui a capacidade de resgatar o indivíduo diante de Deus. Além disso, ela inquieta a história mundial, cuja contemplação se encontra na imanência. Segundo Kierkegaard, quanto mais um ser humano se desenvolve eticamente, menos ele se preocupa com a história mundial, ou seja, ocorre exatamente o contrário do que comumente se pensa. A ética e a história mundial diferem especialmente nisso. Para ele, a ética seria uma espécie de pequeno teatro, e a história mundial seria um grande teatro. Contudo, um grande espírito não se encontra em um grande teatro, mas participando de um pequeno teatro. O caminho da subjetividade é, segundo a visão kierkegaardiana, tão grande que não cessa, por irônico que possa parecer, nem mesmo quando a vida termina. Há uma dificuldade especial para uma consciência não-subjetiva que é explicar a história mundial como um processo abstrato e independente. Contudo, o que é a história mundial senão uma legião de indivíduos criados por Deus? Nessa perspectiva, é necessário que o indivíduo torne-se subjetivo para que se entenda como existente, sendo esse o mais alto dever na visão kierkegaardiana.

O pensador dinamarquês estabelece a seguinte ordem: ética subjetividade - história mundial. Na sua concepção, o próprio homem objetivo se sente bem em sua interioridade. De um modo irônico e mordaz, ele lança a seguinte pergunta: "o que para o sábio é difícil compreender não é justamente o mais simples?". Segundo ele, o simples compreende diretamente, já o sábio problematiza o simples. O sábio, descobrindo-se no não-saber, entra em crise com a ideia da história mundial. Kierkegaard reafirmará o ponto de vista socrático de que sábio é o que não sabe e não o que sabe coisas grandiosas em detrimento daqueles que sabem o essencial. A ética não é somente um saber, mas um agir que se reporta ao saber. Por isso é que ele confessa que Sócrates é o seu consolo. O 
ateniense foi levado, pela ética, a descobrir-se com disposição para o mal; o seu caminho é mais longo que o da história mundial, visto que não é um atalho. Seu caminho não começa quando se descobre, mas quando age.

O importante, segundo o pensador de Copenhague, é o vir-a-ser subjetivo que o sistema não pode oferecer. O sistema acaba por refletir sobre a morte e se esquece da essência real. Ele não vê a morte como um processo que vem da própria existência. Ela é o que há de mais subjetivo e atinge a todos. Hegel fala da imortalidade em seus escritos, mas não no sistema. A explicação de todas as coisas pode significar a sua morte. Para Kierkegaard, por exemplo, uma poesia explicada é uma poesia morta. Por isso, ou o sistema coloca a questão da imortalidade - e com isso se reconhece finito - ou se acha um ícone.

Ao analisar a subjetividade como verdade, Kierkegaard fará menção a dois tipos de verdade: a concepção empírica de verdade, que julga que verdade é adequação entre o pensamento e o ser; e a concepção idealista de verdade, que julga que verdade é a adequação do ser ao pensar. Em ambos os casos, deve-se saber claramente o que se entende por ser, devendo-se também saber se o espírito humano acaso conhece, visto que o espírito humano não se favorece na indeterminação. Em outras palavras, essas são as dúvidas do ser que está no mundo.

Pelo ponto de vista empírico, a verdade é transformada em um desejo. Nesse caso, o objeto não se encerra no espírito que conhece, mas está em devir. Não há uma verdade absoluta, mas uma aproximação retroativa (verdade retroativa). A outra perspectiva para a verdade seria se ela ocorresse em virtude de uma decisão não-imanente, isto é, através da fé. Tal verdade seria, no entender kierkegaardiano, ligada ao existente.

Na visão do pensador da Dinamarca, o problema se encontra no fato de que pensar e ser são vistos abstratamente. A sua proposta é que se enfatize mais a integralidade do ser e menos a abstração. A própria abstração faz abstração contradizendo-se, uma vez que dizia trazer as coisas para o concreto. Em outras palavras, ela comete, segundo o seu entender, uma tautologia. Kierkegaard defende uma unidade entre ser e pensar. Segundo ele, a verdade sempre implica uma reduplicação entre abstrato e concreto; deve haver uma unidade entre ser e pensar, devendo ser essa a pergunta e não a resposta. Para ele, a verdade se encontra no meio entre ser e pensamento, isto é, ela está em devir. Ele lança a ideia de espírito existente, ou seja, só um espírito particular pode colocar essa questão; ela não caberia a alguém que fosse abstrato.

Ao argumentar sobre a defesa da subjetividade, Kierkegaard citará Hamlet, de Shakesperare, na famosa frase "ser ou não ser, eis a questão". Nessa perspectiva, a decisão eterna não reside na abstração, mas na 
subjetividade, ainda que o objetivo se julgue mais seguro que o subjetivo. Se a interioridade pode ser vista como uma loucura, a sua ausência também pode ser indicador de tal enfermidade. Ele indagará se somente aquele que se entende pode ser considerado válido. $O$ autor dinamarquês chega, inclusive, a citar Dom Quixote como modelo de loucura subjetiva ou de paixão interior extremada (ideia fixa). Contudo, para o pensador dinamarquês, há uma loucura bastante pior: a loucura da objetividade. Tal loucura é recitante, copiadora, cômica (pois se pretende séria) e totalmente apática, isto é, sem paixão. Em suma, essa seria a loucura da filosofia sistemática e especulativa. A vantagem da loucura subjetiva é que ela possui um elemento cômico como o trágico, já a loucura objetiva é somente cômica.

A subjetividade é a verdade, visto que é uma interiorização da verdade. Ela é uma eterna busca pela verdade, ao passo que a objetividade julga poder possuí-la, o que é uma quimera e uma fantasia. Afinal, se o homem descobrisse a verdade por si só, ela se acabaria. Na visão kierkegaardiana, o indivíduo deve refletir exatamente essa dialética, isto é, ele é uma síntese de finito e infinito. No instante da paixão o finito acaba por ser tocado pelo infinito. O eu existente reflete essa síntese, enquanto o eu-eu (egoísta) não possui síntese alguma. Essa é a diferença que Kierkegaard aponta entre existir e ser egoísta. Para ele, o conhecimento real se reporta à existência, esse seria o conhecimento essencial. Já o conhecimento ético-religioso reporta-se ao conhecimento essencial e ao fato do sujeito que conhece, de fato, existir.

Um ponto fundamental no pensamento kierkegaardiano é que a abstração tem um desprezo pelo devir, isto é, sempre que existe a ideia de um processo, de um vir-a-ser. Nesse sentido, Kierkegaard questiona a própria ideia de mediação da filosofia sistemática. Para o indivíduo que busca a verdade não é possível alcançá-la por si mesmo. Logo, a subjetividade é a verdade por causa da existência, não por causa da verdade científica. Por isso, para ele, o que vale é a paixão infinita. Notese que essa constatação influi bastante na maneira sistemática do saber teológico (objetivo) e na maneira como o pensador de Copenhague propõe um novo refletir teológico.

A filosofia sistemática e especulativa parece ainda não ter compreendido Sócrates. O posicionamento objetivo trabalha sobre aquilo que é dito, o subjetivo sobre como a coisa é dita. O subjetivo por ser afetado pela paixão do infinito, conduz à verdade. Contudo, ele precisa de uma decisão, de um ato de coragem de um ser que está em devir. Em outras palavras, há um esforço para se tornar subjetivo. Seguindo tal trilha, o subjetivo nada mais seria do que a incerteza objetiva, que parte rumo à verdade, nascendo algo desse choque e antítese, isto é, a fé. 


\section{A subjetividade em Plantinga e o seu possível diálogo com Kierkegaard}

Embora Kierkegaard e Plantinga sejam dois autores que, a princípio, possam ser caracterizados por uma severa distância temporal, espacial e até mesmo de posicionamento filosófico, Evans avalia que uma comparação entre alguns dos argumentos de ambos os autores pode ser de grande valia para os estudiosos da filosofia da religião ${ }^{7}$. Segundo ele, a visão de Kierkegaard se encontra com a perspectiva de Plantinga notadamente na abordagem que ambos possuem da subjetividade como um ponto de central importância para a afirmação da crença religiosa.

Com efeito, tanto para Plantinga como para o pensador dinamarquês a subjetividade é um ponto fundamental na medida em que é a partir da mesma que se pode afirmar a crença em Deus. Nesse sentido, haveria um fecundo diálogo entre os dois autores e ambos deveriam ser vistos para além de seus rótulos, ou seja, nem Plantinga deveria ser visto apenas como um epistemólogo cristão e nem Kierkegaard visto apenas como o pai do existencialismo ou fideísta. Certamente Plantinga parece almejar alguns critérios para a afirmação da crença que não são os mesmos apontados por Kierkegaard, mas ainda assim há, através da análise da subjetividade, um importante ponto de contato entre ambos.

No seu artigo "Razão e crença em Deus", Plantinga afirma que a crença se constitui em algo apropriadamente básico para muitas pessoas e, nesse sentido, podemos aceitá-la sem maiores argumentos ou evidências. A sua estrutura noética seria simples e as suas proposições seriam aceitáveis, mesmo que umas possam ser mais críveis do que outras. Desse modo, algumas coisas teriam apropriadamente base para crença e outras não. Isso é bem indicado pelo próprio Plantinga:

Uma crença pode ser descrita como uma proposição aceita como verdadeira ou como a atitude humana de aceitar a proposição como verdadeira, mas os dois enfoques estão sempre unidos. O fundacionismo baseia-se na observação de que boa parte das crenças que alguém sustenta baseia-se em outras crenças, ou seja, funda-se nelas, mas isso

7 Refiro-me aqui especialmente ao artigo "Kierkegaard and Plantinga on Belief in God: Subjectivity as the Ground of Properly Basic Religious Beliefs", publicado in: C. S. Evans, Kierkegaard on Faith and the Self - Collected Essays, Waco: Baylor University Press, 2006.

8 PLANTINGA, A. "Reason and belief in God". In: PLANTINGA, A;WOLTERSTORFF, N. (Ed.). Faith and rationality: reason and belief in God. Notre Dame: University of Notre Dame Press, 1983. p. 16-93. 
não pode ser verdade para todas as crenças; pelo menos algumas delas são aceitas sem base em outras ${ }^{9}$.

Com efeito, a argumentação de Plantinga sobre a crença apropriadamente básica é uma defesa da racionalidade da crença em Deus. Cabe frisar que o termo apropriação possui fortes semelhanças com Kierkegaard. A fé, no entender do autor dinamarquês, possui na apropriação um aspecto essencial. O subjetivo se afirma exatamente aí, quando algo se constitui em uma verdade para mim, mesmo que Plantinga aponte critérios para tal afirmação.

O fundacionismo clássico é, por isso, severamente criticado por Plantinga, pois, no seu entender, a crença em Deus não necessita de nenhuma demonstração ou evidência. A sua base é a experiência ${ }^{10}$. Por isso, Plantinga defende o externalismo e se posiciona contrariamente ao evidencialismo ${ }^{11}$. Para ele, a crença equivale a uma proposição que não se baseia em outra proposição. Trata-se de uma estrutura noética simples. Por outro lado, a rejeição da crença em Deus pelos fundacionistas não é apropriadamente básica e nem se funda em nenhuma evidência. Para Plantinga, Deus pode ser aceito sem nenhum tipo de evidência ou prova. Aqui entra novamente a estreita relação de Plantinga com a epistemologia reformada, pois, baseado em Calvino e em teses que ressoarão em teólogos reformados como Herman Bavinck, ele defenderá a tese do sensus divinitatis ("senso de divindade"), que cada ser humano possui. Mas o que é o sensus divinitatis? Ele é formado a partir da contemplação da natureza e da observação das leis morais, como bem observa Plantinga:

Usando a terminologia de Calvino, há o sensus divinitatis, que é uma fonte de crença em Deus, e o testemunho interno do Espírito Santo, que é a fonte da crença nas doutrinas próprias do cristianismo. As crenças produzidas por estas fontes ultrapassam a razão no sentido de que a fonte do seu aval não é o que a razão nos dá; claro que não se segue que tais crenças são irracionais, ou contrárias à razão; nem se segue que há algo nelas de especialmente arriscado ou inseguro, ou incerto, como se a fé fosse necessariamente cega ou um salto no escuro. $\mathrm{Na}$ verdade, João Calvino define a fé como "um conhecimento firme e certo da benevolência de Deus para conosco [...]" (Calvino 1559, p. 551, itálico

9 PLANTINGA, A. "Is belief in God properly basic?". In: SWEETMAN, BRENDAM; GEIVETT, R. Douglas (Ed.). Contemporary perspectives on religious epistemology. New York:Oxford University Press, 1992, p. 133.

10 Para os interessados em maiores informações sobre o conceito de experiência em Plantinga sugerimos o artigo de Pinheiro, citado em nossa bibliografia final.

11 Não é meu intuito aprofundar tal discussão aqui. 
meu). Deste ponto de vista, a religião e a fé têm uma fonte de crença apropriadamente racional independente da razão e da ciência; seria, portanto, possível que a religião e a fé corrigissem a ciência e a razão, e também que fossem por essas corrigidas ${ }^{12}$.

O problema agora é saber em que circunstâncias ocorre o sensus divinitatis, pois é exatamente nele que Plantinga baseará o seu critério para a crença. Por isso, segundo avaliamos, Pinheiro tem razão no seu questionamento:

"Que circunstâncias seriam essas? Em primeiro lugar, destacam-se aquelas ligadas à contemplação dos grandes espetáculos da natureza: o céu noturno estrelado, a imensidão do mar, a fascinação e o terror causados pelo imenso poder das forças naturais, etc. Plantinga acrescenta outras circunstâncias igualmente deflagradoras da atividade do sensus divinitatis, especialmente relacionadas à experiência moral. Por exemplo, quando alguém se sente culpado por ter feito algo moralmente errado, pode "sentir" a desaprovação divina. Ou então, podem ocorrer outras circunstâncias ligadas a situações de perigo, situações de estresse, etc., em que se pode sentir a proteção de Deus"13.

Para tal tese, o ato de crer é um pressuposto, não precisando nenhum tipo de argumento. Notemos aqui a estreita relação também com Karl Barth, Anselmo (na questão do pressuposto e não das provas) e Kierkegaard. Contudo, é preciso determinar claramente um critério para a basicalidade. Afinal, segundo Plantinga, não é qualquer crença que possui base. A crença, incluindo-se aqui a crença em Deus, só é básica se atende certas condições. Parece haver aqui uma discordância entre Kierkegaard e Plantinga. O dinamarquês acredita no páthos da crença, tal como se pode perceber:

Quando um homem que vive no seio do cristianismo vai ao templo de Deus, do verdadeiro Deus, possuindo ele a verdadeira concepção de Deus, e lhe faz uma prece, mas não num espírito verdadeiro; e um outro que vive numa terra de pagãos ora com toda a paixão do infinito, mesmo que seus olhos repousem sobre a imagem de um ídolo: onde existirá mais verdade? Um ora a Deus em verdade, ainda que adore um ídolo; o outro ora para o verdadeiro Deus, mas não no espírito da verdade e, verdadeiramente, ele adora um ídolo ${ }^{14}$.

12 Cf. Alvin Plantinga, Religião e ciência, in: Critica na Rede, www.criticanarede.com. Tradução de Desidério Murcho. Acessado em 22.08.2011.

${ }^{13}$ Cf. M. M. S. Pinheiro, Experiência Religiosa e Garantia da Crença na Existência de Deus Alvin Plantinga, in: Numen: Revista de Estudos e Pesquisa da Religião, v. 9, (2006), p. 09.

14 Cf. S. A Kierkegaard, Post-Scriptum Définitif et Non Scientifique aux Miettes Philosophiques, vol. I/II, Oeuvres Complètes, vol.10/11, Paris: Éditions L'Orante, 1977, p. 187. 
O elo comum entre as crenças e a crença religiosa é a experiência. Contudo, a experiência religiosa possui uma relação fenomenológica e existencial com o seu objeto, o que não lhe a torna absurda no entender de Plantinga. Por isso, a crença forçada é absurda. Não se trata aqui de busca por evidência, mas por base. A tentativa de justificar crenças por evidências é internalista, já a justificação de crença por bases é externalista. Essa última é a posição de Plantinga. Tal como se pode notar pela sua própria posição:

Ao ler a Bíblia, pode-se ficar impressionado com o profundo sentido de que Deus nos fala. Depois de fazer o que considero reles, ou imoral ou malévolo, posso sentir-me culpado aos olhos de Deus e formar a crença Deus desaprova o que fiz. Ao confessar-me e arrepender-me, posso sentirme perdoado formando a crença Deus perdoa-me o que fiz. Uma pessoa em grave perigo pode voltar-se para Deus, pedindo-lhe proteção e ajuda; e claro que ele ou ela formará então a crença de que Deus é de fato capaz de ouvir e ajudar se o considerar apropriado. Quando a vida é doce e gratificante, um sentido espontâneo de gratidão pode ascender na alma; alguém nesta condição pode agradecer e louvar o Senhor pela bondade e formará evidentemente a crença concomitante de que na verdade há que agradecer ao Senhor e louvá-lo ${ }^{15}$.

Tal posicionamento não é tranqüilo e pode suscitar muitas críticas. Como, por exemplo, a de Faria, que aponta, a partir da defesa de tal tese, a possibilidade de defesa de diversos fundamentalismos religiosos, uma vez que os mesmos também são legitimados nas comunidades ${ }^{16}$.

Voltemos novamente à comparação com Kierkegaard. Evans aponta, de modo bastante instigante, que em Plantinga as proposições "crer em Deus" e crer na proposição "Deus existe" não parecem ser tão distintas assim. Kierkegaard certamente teria objeção em concordar com tal coisa. A proposição "Deus existe" não é básica para ele, mas sim a proposição "Deus fala comigo" ou "Deus desaprova o que faço". Portanto, as duas últimas proposições só podem se afirmar exatamente na subjetividade ou interioridade de um indivíduo.

Para Kierkegaard, a fé não pode se constituir em um assentimento intelectual, mas antes se afirma na concretização da fé em Deus. Tal coisa é fruto da escolha de um indivíduo concreto, que opta por tal coisa. Parece que aqui, nesse ponto, Plantinga não discordaria de Kierkegaard. No entender do pensador dinamarquês, a fé pode ser compreendida como

15 Cf. A. Plantinga, Será a crença em Deus apropriadamente básica?, in: D. Murcho (org), A ética da crença, Lisboa: Bizâncio, 2010, p. 186.

16 Cf. D. Faria, A epistemologia reformista de Plantinga, in: Critica na Rede, www. criticanarede.com. Acessado em 22.08.2011. 
absurda e até mesmo como contrária a um dado tipo de racionalidade. Há notadamente no capítulo terceiro das Migalhas Filosóficas uma severa crítica a qualquer tipo de teologia natural. Segundo ele, a existência de Deus se afirma sempre pela posição de adoração e seguimento do fiel, jamais podendo ser reconhecida por provas de qualquer natureza.

Há aqui outro curioso ponto de aproximação. Tanto em Kierkegaard como em Plantinga, Deus não necessita de provas. Ou melhor, para muitas pessoas, aquelas que possuem as suas crenças apropriadamente básicas, Deus é uma realidade e, por esse motivo, não implica em provas ou explicações. Tal situação faz com que muitos acusem Kierkegaard de fideísta, mas não parece que isso seja correto. Afinal, um autor de imensa produção intelectual, de inúmeros pseudônimos e de diálogo com grandes filósofos, articula, de modo racional, a sua estratégia e comunicação, não defendendo nenhuma espécie de fé cega ou algo do gênero.

$\mathrm{O}$ que Plantinga parece querer apontar quando disserta acerca de crenças apropriadamente básicas? Percebe-se aqui a sua crítica marcante aos fundacionistas clássicos como Tomás de Aquino e Descartes, por exemplo. Talvez, o primeiro a ser aqui percebido é a diferença entre a existência de Deus e a crença nele. A existência de Deus é apropriadamente básica, mas não a crença nele. Para Plantinga, se as crenças podem ser consideradas irracionais, como parece acreditar boa parte da modernidade, o próprio fundacionismo seria irracional. Além disso, o fundacionismo é auto-referente. Desse modo, a crença é efetivamente básica e deve ser aceita. Há, aqui, outro notável ponto de contato entre Kierkegaard e Plantinga. O autor dinamarquês defende uma epistemologia luterana, que sempre tende a ter maiores problemas com um dado tipo de racionalidade, seguindo a esteira de algumas das críticas de Lutero. Plantinga, por sua vez, desenvolve as suas teses a partir da epistemologia reformada e, segundo se pode notar, Calvino e a sua tradição parecem articular melhor um tipo de relação entre fé e conhecimento.

Kierkegaard parece que seria contrário tanto ao fundacionismo como ao ceticismo. Para Plantinga, por sua vez, existiriam critérios para as crenças e a mera afirmação subjetiva de qualquer uma delas não poderia nos dar qualquer garantia. Entretanto, ao contrário do que pensou a modernidade, Plantinga não elimina o sujeito (e nem o transforma em sujeito pensante) para afirmar a crença. Nesse ponto, ele se encontra com Kierkegaard, que talvez não tivesse dificuldade em afirmar que todas as crenças apropriadamente básicas são fundamentadas, no seu entender, na experiência. Para Plantinga, a crença é justificada pelo que crê, mas dentro de circunstância que validam a sua justificação, o que, como vimos, também é polêmico. Em ambos os autores, a tendência 
para crer é suprimida pelo pecado e, a partir disso, o subjetivo torna-se o fundamento para a afirmação da crença em Deus. Parece não importar aqui se tal coisa é chamada de interioridade, para Kierkegaard, ou de circunstância justificada, para Plantinga. Desse modo, com diferentes nuances, o aspecto subjetivo é fundamental para ambos.

\section{Referências}

CARVALHO, G. V. R. de. A 'basicalidade' da crença em Deus segundo Alvin Plantinga: uma apresentação. In: Horizonte, v. 4, n. 8 (2006), p. 97-113.

CLAIR, A. Kierkegaard, penser le singulier. Paris: Cerf, 1993.

CLAIR, A. Pseudonymie et Paradoxe. La pensée dialectique de Kierkegaard. Paris: J. Vrin, 1976.

EVANS, C. S. Kierkegaard on Faith and the Self - Collected Essays. Waco: Baylor University Press, 2006.

FARIA, D. A epistemologia reformista de Plantinga. In: Critica na Rede. www. criticanarede.com. Acessado em 22.08.2011.

KIERKEGAARD, S. A. Post-Scriptum Définitif et Non Scientifique aux Miettes Philosophiques, vol. I/II. Oeuvres Complètes, vol. 10/11. Paris: Éditions L'Orante, 1977.

MURCHO, D. Fé, epistemologia e virtude. In: Critica na Rede. www.criticanarede. com. Acessado em 22.08.2011.

PINHEIRO, M. M. S. Experiência religiosa e garantia da crença na existência de Deus Alvin Plantinga. In: Numen: Revista de Estudos e Pesquisa da Religião, v. 9, (2006), p. 93-110.

PLANTINGA, A. Is Belief in God Properly Basic? In: SWEETMAN, Brendam; GEIVETT, R. Douglas (eds.). Contemporary Perspectives on Religious Epistemology. New York: Oxford University Press, 1992, p. 133-141.

PLANTINGA, A. Reason and Belief in God. In: PLANTINGA, A ; WOLTERSTORFF, N. (eds.). Faith and Rationality: Reason and Belief in God. Notre Dame: University of Notre Dame Press, 1983, p. 16-93.

PLANTINGA, A. Religião e ciência. In: Critica na Rede, www.criticanarede.com. Tradução de Desidério Murcho. Acessado em 22.08.2011.

PLANTINGA, A. Será a Crença em Deus Apropriadamente Básica? In: MURCHO, D. (org). A ética da crença. Lisboa: Bizâncio, 2010, p. 175-196.

TILLICH, Paul. História do pensamento cristão. São Paulo: Aste, 1988. 